\title{
A five year study of maternal mortality in Mandya district, Karnataka, India
}

\section{Pradeep Musale Ramachandra*, Rangaswamy Manohar}

Department of Obstetrics and Gynaecology, Mandya institute of medical sciences, Mandya, Karnataka, India

Received: 12 March 2016

Accepted: 13 April 2016

\section{*Correspondence:}

Dr. Pradeep Musale Ramachandra,

E-mail: majormrp@gmail.com

Copyright: () the author(s), publisher and licensee Medip Academy. This is an open-access article distributed under the terms of the Creative Commons Attribution Non-Commercial License, which permits unrestricted non-commercial use, distribution, and reproduction in any medium, provided the original work is properly cited.

\section{ABSTRACT}

Background: Maternal mortality is a quality health care of that area. We planned a study on maternal mortality ratio (MMR) to understand the causes leading to maternal mortality in Mandya district, Karnataka, India after the introduction of national rural health scheme in past five years.

Methods: It is a retrospective analysis of case records. We collected records of MMR occurred from Jan 2011 to Dec 2015 over a period of five years from district health office.

Results: MMR from Jan 2011 to Dec 2015 is 38.25/lakh live births the same was 106.9 (in 2001-05) and 95.89 (2006-10). MMR commonly seen between 20-29years and most of them died within 24 hours of admission. Postpartum haemorrage (PPH), eclampsia and amniotic embolism are still the leading causes, anaemia plays a major role (10\% direct and $37.5 \%$ indirect cause) of maternal mortality.

Conclusions: Introduction of NRHM certainly helped to reduce MMR in our district. MMR by Anaemia, PPH and eclampsia are largely preventable on early recognition and aggressive treatment by skilled birth attendants.

Keywords: Maternal mortality, Skilled birth attendents, Anaemia

\section{INTRODUCTION}

Maternal mortality is an index of quality of health care of that area. It is defined as "death of a woman while pregnant or within 42 days of termination of pregnancy irrespective of the duration or site of pregnancy from any cause related to or aggravated by pregnancy or its management but not from accidental or incidental causes". Improving maternal health and reducing maternal mortality have been key concern all over globe particularly in India since 1980 to till date. At the country level, the two countries that accounted for one third of all global maternal deaths are India at $17 \%$ and Nigeria at $14 \%$. The maternal mortality ratio (MMR) in developing regions (230) was 14 times higher than in developed regions (16).WHO concluded improving maternal death reviews, evidence and innovation, development and implementation of dual short-term and long term strategies will help in decreasing MMR. ${ }^{1}$
The Office of the Registrar General, India under the Ministry of Home Affairs in Dec 2013 declared maternal mortality in India as 178 in 2010-12. ${ }^{2}$ Maternal mortality study in Madhya Pradesh, India showed $81 \%$ of all maternal deaths can be prevented through proper understanding diagnosis and management of labor complications. ${ }^{3}$

The reasons that women die in pregnancy and childbirth are many layered. Behind the medical causes are logistic causes, failure in healthcare system, lack of transport etc. and behind these are social, cultural and political factors which together determine the status of women, their health, fertility and health seeking behavior. ${ }^{4}$

Keeping this in mind this study is planned to understand the causes leading to maternal mortality in Mandya district,India. 


\section{METHODS}

This is a retrospective study, done by studying maternal mortality case records in Mandya district health office from Jan 2011 to Dec 2015.

Case records will be analyzed year wise in relation to distribution of deliveries and maternal deaths, age and parity, when death occurred-antenatal, intra, postnatal period, place of delivery, place of death, delivery conducted by whom, and cause of death for the period of five years.

\section{Inclusion criteria}

- Death of a pregnant lady

- Death of lady within 42 days of termination of pregnancy

\section{Exclusion criteria}

Death of pregnant lady due to accidental/incidental causes.

\section{RESULT}

In the study, there were total of 40 maternal deaths in a span of five years for 104569 deliveries in Mandya district with MMR of 38.25/lakh live births (Table 1).

25-29yrs is the most common age group with $42.5 \%$ followed by $20-24$ years $(35 \%)$ had maternal mortality in the study (Table 2).
Table 1: Maternal mortality and live births with MMR year wise.

\begin{tabular}{|llll|}
\hline Year & $\begin{array}{l}\text { No. of maternal } \\
\text { deaths }\end{array}$ & $\begin{array}{l}\text { No. of live } \\
\text { births }\end{array}$ & $\begin{array}{l}\text { MMR/lakh } \\
\text { live births }\end{array}$ \\
\hline 2011 & 10 & 21899 & 45.66 \\
\hline 2012 & 9 & 21399 & 42.05 \\
\hline 2013 & 7 & 21075 & 33.21 \\
\hline 2014 & 6 & 20274 & 29.59 \\
\hline 2015 & 8 & 19922 & 40.15 \\
\hline Total & 40 & 104569 & 38.25 \\
\hline
\end{tabular}

Table 2: Maternal mortality with age wise distribution and its percentage.

\begin{tabular}{|ll|l|}
\hline $\begin{array}{l}\text { Age wise } \\
\text { distribution }\end{array}$ & No. of maternal deaths & Percentage \\
\hline$<20$ years & 1 & 2.5 \\
\hline 20- 24 years & 14 & 35.0 \\
\hline 25-29 years & 17 & 42.5 \\
\hline 30- 34 years & 4 & 10.0 \\
\hline 35- 39 years & 4 & 10.0 \\
\hline
\end{tabular}

Most of the maternal mortality 27/40 occurred within 24hr. 16 out of 27 deaths occurred in 4-24 hours of admission. A case of eclampsia, one with haemorrhagic shock, a case of puerperal sepsis (discharged against advice) and a case of preeclampsia with pulmonary edema died at home/on the way to the hospital (Table 3).

All had ANC registration at subcentre, PHC, CHC or in private hospital. $35 \%$ had irregular ANC (Table 4).

Table 3: Distribution of maternal mortality in relation to admission to the hospital and time of death year wise.

\begin{tabular}{|lllllll|}
\hline Admission to death interval & 2011 & 2012 & 2013 & 2014 & 2015 & Total \\
\hline On the way to hospital/home & & 1 & 1 & & 02 & 04 \\
\hline Less than 4 hrs & 05 & 2 & & & 03 & 07 \\
\hline 4- 24 hrs & 04 & 3 & 02 & 04 & 2 & 02 \\
\hline 24- 48 hrs & & & & & 01 & 01 \\
\hline 48- 72 hrs & & 1 & 01 & & 01 & 04 \\
\hline 3- 7 days & 01 & 1 & 01 & 01 & & 04 \\
\hline 7- 10 days & & & & & 01 \\
\hline
\end{tabular}

Table 4: Showing regular/irregular ANC with percentage.

\begin{tabular}{|lll|}
\hline ANC registration & No. of maternal death & Percentage \\
\hline Regular ANC & 26 & 65.00 \\
\hline $\begin{array}{l}\text { irregular } \\
\text { ANC/unboked cases }\end{array}$ & 14 & 35.00 \\
\hline
\end{tabular}

Most of pregnant women died in intranatal period. Most common cause of death during antenatal period was eclampsia (Table 5).
Table 5: Death of pregnant ladies in relation to antenatal, intra-natal and post-natal period.

\begin{tabular}{|lll|}
\hline Died during & No. of maternal deatl & Percentage \\
\hline Antenatal period & 7 & 17.5 \\
\hline Intranatal period & 23 & 57.5 \\
\hline Early puerperium & 10 & 25.0 \\
\hline
\end{tabular}

Maternal motality is almost same in primi and multigravida (Table 6). 
Table 6: Distribution of maternal deaths and gravidity.

\begin{tabular}{|lll|}
\hline & No. of maternal deaths & Percentage \\
\hline Primi gravida & 18 & 45.00 \\
\hline Multigavida & 20 & 50.00 \\
\hline Grand multi & 2 & 05.00 \\
\hline
\end{tabular}

Maternal mortality is little higher in caesarean delivery than vaginal group (Table 7).

Table 7: Maternal deaths in relation to timing and route of delivery.

\begin{tabular}{|lll|}
\hline & No. of maternal deaths & Percentage \\
\hline Before delivery & 07 & 17.5 \\
\hline vaginal delivery & 16 & 40 \\
\hline LSCS delivery & 17 & 42.5 \\
\hline
\end{tabular}

Post partum hemorrhage is the most common cause of maternal mortality of $32.5 \%$ followed by eclampsia (15\%) and amniotic fluid embolism (12.5\%) most of them not accepted for postmortem.

Anaemia is present in majority of the cases i.e., in post partum hemorrhage, sepsis, and also involved in heart failure (Table 8).

Table 8: Different causes of maternal mortality and its percentage.

\begin{tabular}{|c|c|c|}
\hline Causes of maternal mortality & No. & Percentage \\
\hline Post partum hemorrhage & 13 & 32.5 \\
\hline $\begin{array}{l}\text { Eclampsia and its } \\
\text { complications }\end{array}$ & 6 & 15 \\
\hline Amniotic fluid embolism & 5 & 12.5 \\
\hline Severe anaemia in failure & 4 & 10 \\
\hline Puerperal Sepsis & 2 & 5 \\
\hline post abortion with DIC & 1 & 2.5 \\
\hline $\begin{array}{l}\text { Complication of anaesthesia } \\
\text { (spinal shock) }\end{array}$ & 1 & 2.5 \\
\hline Dilated cardiomyopathy & 1 & 2.5 \\
\hline Obstructed labour & 1 & 2.5 \\
\hline $\begin{array}{l}\text { Hollow viscus perforation } \\
\text { with peritonitis(after LSCS) }\end{array}$ & 1 & 2.5 \\
\hline $\begin{array}{l}\text { Transfusion related acute } \\
\text { lung injury }\end{array}$ & 1 & 2.5 \\
\hline $\begin{array}{l}\text { Medical disorders } \\
\text { Status epilpeticus-1 } \\
\text { Acute fulminant hepatitis-1 } \\
\text { Pulmonary kochs with } \\
\text { abdominal preg (optd) } \\
\text { MODS-1 } \\
\text { Pneumonia with cardio } \\
\text { respiratory failure -1 }\end{array}$ & 4 & 10 \\
\hline
\end{tabular}

$70 \%$ of MMR is directly related to pregnancy complications (Table 9).

Table 9: Direct and indirect causes of MMR and its percentage.

\begin{tabular}{|lll|}
\hline Direct causes of MMR & 28 & $70 \%$ \\
\hline Indirect causes of MMR & 12 & $30 \%$ \\
\hline
\end{tabular}

\section{DISCUSSION}

MMR in Mandya district was 106.9/lakh live births in 2001-2005 and it was 95.89/lakh live births between 2006-10. With effective implementation of NRHM programme, training skilled birth attendents and awareness in people has reduced MMR to 38.25/lakh live births in 2011-2015.

In these five years in our district, post-partum hemorrhage is the leading cause of MMR of 30\%. This is associated with co-morbidities like anaemia ( 8 cases) Placenta previa ( 2 cases), previous two caesarean (3 cases) both atonic and traumatic PPH (2 cases)

In majority of cases there was a delay in recognition of PPH and treatment/referral.

Pre-eclampsia and its complications is the second leading cause of maternal mortality in our study. Most of the cases were not recognized in antenatal checkups (irregular ANC). Four died in antenatal period majority had aspiration during convulsions.

Anaemia is present in almost all the cases of maternal mortality. Four cases had Severe/very severe anemia lead to death because of heart failure in $\mathrm{IV}^{\text {th }}$ stage two of them migrated from other district during pregnancy for occupation and had no ANC, other two were unbooked cases.

Case records showed five cases of sudden deaths attributed to amniotic embolism, none of them had post mortem report.

Common conditions like anaemia, eclampsia and postpartum hemorrhage are the leading causes of maternal mortality reflecting lack of antenatal care and timely referral as observed in Naik $S$ et al and Jadhav et al.,

\section{CONCLUSIONS}

With effective implementation of NRHM (National rural health mission) in our district maternal mortality is decreased from 95.89 to 38.25 /lakh live births in these five years.

Post-partum hemorrhage, eclampsia and anaemia are still the leading causes of maternal mortality. Anaemia is the direct cause in $10 \%$ and as indirect causes in PPH, and sepsis, $(37.5 \%)$ 
All leading causes like PPH, eclampsia and anaemia are largely preventable. Training SBA (skilled birth attendants) for early recognition/referral and aggressive treatment on these co-morbidities may help in further reduction of MMR.

Funding: No funding sources

Conflict of interest: None declared

Ethical approval: The study was approved by the Institutional Ethics Committee

\section{REFERENCES}

1. Trends in maternal mortality 1990 to 2013 , estimates by WHO, UNICEF, UNFPA the World Bank and the United Nations population division, page 1-68.
2. Special bulletin on maternal mortality in India 201012, office of registrar general India, dec 2013 page 14.

3. Yadav K, Namdev, Bhargava. A retrospective and prospective study of maternal mortality in a rural tertiary care hospital of central India, Indian $\mathrm{J}$ community health.2013;25(1):16-21.

4. Bedi N, Kambo I, Dhillon BS, Saxena BN, Singh P. Maternal deaths in India: preventable tragedies (An ICMR Task Force Study)J Obstet Gynecol Ind.2001;51:86-92.

5. Naik s.sambarey P W, pawar S, A clinical Review of maternal mortality over a decade lessons learnt, Medical J of westeren India.2010;38:65-71.

6. Jadhav A, Rote P. Maternal mortality: changing trends, jour of obstetrics and gynecology of India.2007;57(5):398-400.

Cite this article as: Pradeep MR, Rangaswamy M. A five year study of maternal mortality in Mandya district, Karnataka, India. Int J Reprod Contracept Obstet Gynecol 2016;5:1585-8. 